\title{
Comparison of child morbidity in regions of Ostrava, Czech Republic, with different degrees of pollution: a retrospective cohort study
}

\author{
Miroslav Dostal ${ }^{* *}$, Anna Pastorkova ${ }^{1}$, Stepan Rychlik² ${ }^{2}$ Eva Rychlikova ${ }^{3}$, Vlasta Svecova $^{1}$, Eva Schallerova $^{4}$
} and Radim J Sram ${ }^{1}$

\begin{abstract}
Background: To confirm or refute the hypothesis that the morbidity of children (since birth to age 5) born and living in the heavily polluted (PM 10 , benzo[a]pyrene) eastern part of Ostrava, Czech Republic, was higher than the morbidity of children living in other parts of the city.

Methods: Ten pediatricians in 5 districts of Ostrava abstracted the medical records of 1878 children born in 20012004 to list all illnesses of each child in ICD-10 codes. The children were divided into four groups according to their residence at birth and thereafter. Most of the children in the eastern area were living in the city district Radvanice and Bartovice.

Results: We report on the incidence of acute illnesses in 1535 children of Czech ethnicity in the first 5 years of life. The most frequent acute illnesses (over $45 \%$ of all diagnoses) were upper respiratory infections (URI: J00-J02, J06). In the first year of life, the incidence of URI in 183 children in the eastern area - 372 illnesses/100 children/year - was more than twice as high as in the other 3 areas with a total number of 1352 children. From birth to the age of 5 years, the incidences of pneumonia, tonsillitis, viral infections (ICD-10 code B34) and intestinal infectious diseases were also several times higher in children living in the eastern part of Ostrava. The lowest morbidity was found in children living in the less polluted western part of the city.

Conclusions: The children born and living in the eastern part of the city of Ostrava had from birth through 5 years significantly higher incidence rates of acute illnesses than children in other parts of Ostrava. They also had a higher prevalence of wheezing, atopic dermatitis and allergic rhinitis.
\end{abstract}

Keywords: Ostrava, Children, Age-specific morbidity, Incidence, ICD-10, Wheezing, Benzo[a]pyrene, PM 10

\section{Background}

The city of Ostrava is the largest industrial city in the Moravian-Silesian region (MSR) of the Czech Republic. This region is bordered on the west, east and partially also on the south by mountains, forming a basin with frequent winter temperature inversions. The region is a heavily polluted industrial area. Concentrations of $\mathrm{PM}_{10}, \mathrm{PM}_{2.5}$, and benzo[a]pyrene $(\mathrm{B}[\mathrm{a}] \mathrm{P})$ significantly exceed limit values [1]. The most important industrial sources of air pollution are metallurgy, steel plants, coke ovens and power generating facilities [2]. The population density in the MSR is

\footnotetext{
* Correspondence: dostal@biomed.cas.cz

'Institute of Experimental Medicine AS CR, Prague, Czech Republic

Full list of author information is available at the end of the article
}

also associated with high-intensity local vehicular transport and local heating. Almost fifty percent of the MSR inhabitants use central heating, 34\% natural gas, 10\% coal, $3 \%$ electricity, and $3 \%$ wood [3]. The prevailing wind direction in Ostrava is SW (especially in winter), with NE winds being the second most frequent. The episodes of highest immissions depend on the wind direction and speed, locality and season [4]. A contribution of sources located on Polish territory to the air pollution load in the city of Ostrava cannot be excluded [5]. Among the extremely polluted areas is the Ostrava city district Radvanice and Bartovice (R\&B, Figure 1). One part of the research project Airgen aimed at analyzing the morbidity of children in Ostrava to confirm the hypothesis that

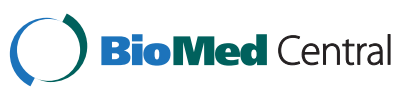




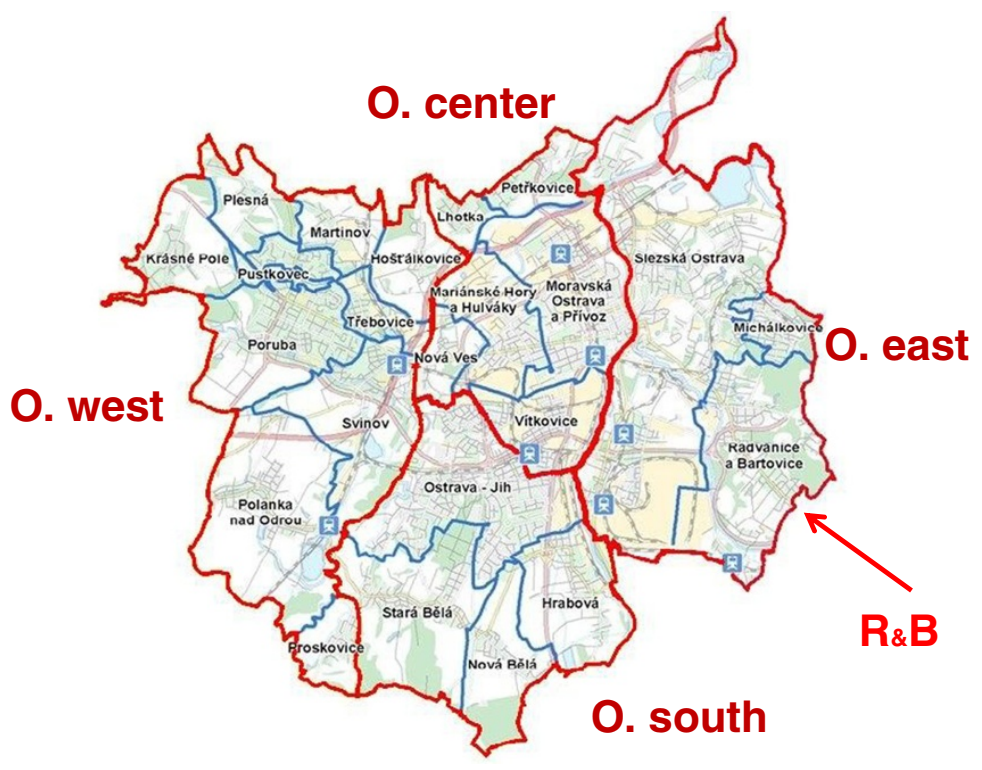

Figure 1 The four regions of the city of Ostrava.

children living in a polluted environment in R\&B suffer more frequently from acute respiratory infections than children living in cleaner parts of Ostrava. We have compared the incidence rates of respiratory infections and other acute illnesses as well as the prevalence of allergic diseases in preschool children registered at 10 pediatric offices in 5 districts of the city of Ostrava.

\section{Methods}

Ostrava study

In 2009 and 2010 a total of 1887 children born in 20012004 and registered with 10 pediatric offices in 5 districts of the city of Ostrava took part in the study. An informed consent signed by the parents was approved by the Ethical Committee of the Institute of Experimental Medicine of the Czech Academy of Sciences. Mothers were asked to complete a written questionnaire on the home environment of the child, including indoor air pollution sources and other factors potentially related to respiratory illnesses, i.e., breastfeeding, day-care, the number of older siblings, the number of smokers in the household, the type of flat, heating of the flat, family history of allergies, keeping pets, mold and dampness in flat etc. We have also asked mothers to give pediatricians an informed parental permission to inform us about the present health status of children and all illnesses they suffeered from birth to the age of 6 . We have not done any further follow-up or collected any biological samples.

The pediatric questionnaire included information about delivery, breastfeeding, congenital defects, serious chronic illnesses, allergies and the results of skin testing. The pediatricians abstracted their medical documentation to list in the codes of International Classification of Diseases, Tenth Revision (ICD-10) all illnesses of the child from birth to the age of 6 years. For the purpose of analysis, the diagnoses were integrated into broader groups (Table 1).

\section{Geographical stratification according to the levels of ambient pollution}

In 1997 Williams et al. [6] followed the exposure of adults to benzo[a]pyrene in Ostrava using both personal and stationary monitors. To this end they divided Ostrava into three regions according to previous studies that mapped pollution by organics. The first region consisted of the western part of the city, while the eastern part was divided horizontally (approximately in the middle) into northeastern and southeastern regions. Because of high levels of $\mathrm{PM}_{10}$ and benzo[a]pyrene monitored in recent years in

Table 1 The major disease groups in children of Czech ethnicity from birth to age of 5

\begin{tabular}{llcc}
\hline $\begin{array}{l}\text { Group of } \\
\text { diseases }\end{array}$ & ICD-10 codes & $\begin{array}{c}\text { Frequency } \\
\text { of dg }\end{array}$ & $\begin{array}{c}\text { \% of } \\
\text { total }\end{array}$ \\
\hline Pneumonia & J12, J14-16, J18 & 202 & 0.7 \\
Otitis media & H65-67, H92 & 961 & 3.5 \\
Intestinal infectious diseases & A02-04, A08-09 & 1,274 & 4.7 \\
Acute laryngitis and tracheitis & J04 & 1,722 & 6.3 \\
Viral illnesses & B15, B18, B24-27, B34 & 1,898 & 6.9 \\
Acute tonsillitis & J03 & 2,092 & 7.6 \\
Acute bronchitis & J20-21, J40 & 2,214 & 8.1 \\
Upper respiratory infections & J00-J02, J06 & 12,964 & 47.4 \\
All diagnoses of acute illnesses & & 27,368 & 100.0 \\
\hline
\end{tabular}


the eastern part of the city of Ostrava, we have further divided the northeastern region and thus we distinguish four Ostrava regions: west, center, east and south (Figure 1). The yearly means of $\mathrm{PM}_{10}$ for each locality of residence were calculated using GIS and the data from surrounding monitoring stations in Ostrava, also taking into consideration the prevailing wind direction. The concentrations of $\mathrm{PM}_{10}$ were determined by two-dimensional interpolation of data from the nearest monitoring stations. The total means of $\mathrm{PM}_{10}$ for the four Ostrava regions were weighted by the number of children taking part in our study in each locality (Table 2 ). The yearly means of $\mathrm{B}[\mathrm{a}] \mathrm{P}$ are values measured by stationary monitoring stations in $\mathrm{O}$. east, west and center. There are no data for O. south (Table 2).

\section{Children}

In the Czech Republic each child has to be registered with a pediatrician. In 8 out of 10 participating pediatric offices, more than $90 \%$ of registered children (1583 children) took part in the study. In the remaining two offices $69.7 \%$ and $74.1 \%$ of registered children participated (304 children). In total 1887 children took part in the study. Subsequently applied exclusion criteria included being born outside Ostrava (92 children), birth weight $<1500$ grams (54 children), congenital defects, tumors, cerebral palsy and longterm preventive administration of antibiotics (27 children), incomplete medical documentation ( 5 children) and a stay in a children's home $(1$ child). The present report is focused on children of Czech ethnicity since their lifestyle and proneness to allergies differ from those of Roma children [7]. The analysis of morbidity was also limited to children born in at least the 36th week of gestation and still living in the same region of Ostrava where they were born. The follow-up of children who spent in the current year less than 11 month at the original address (i.e., region of Ostrava) was discontinued. Therefore, the number of children in the present study decreased from 1535 in the first year of life to 1404 in the 5 th year (Table 3). We do not report on the morbidity of children in the 6th year of life because we do not have the data for children born in 2004. The diagnoses of particular illnesses in ICD-10 codes were merged into broader groups (Table 1). The group of upper respiratory infections (URI) included codes for the diagnoses acute nasopharyngitis (common cold, J00), acute pharyngitis (J02) and acute upper respiratory infections of multiple and unspecified sites (J06).

\section{Statistics}

The Kruskal-Wallis equality-of-populations rank test was used for bivariate analyses. Given that the frequencies of most illnesses in individual children were extremely variable, negative binomial regression, suitable for overspread variables, was used for multivariate analyses of the associations of the regions of residence with the incidence rates of respiratory illnesses. The significance of associations was determined by the rate ratio (RR), statistically significant probability and a $95 \%$ confidence interval not including the value 1 . Confounders were determined by changes in the regression coefficient of more than $15 \%$ after removal of the variable. All tests were performed using STATA 12 software.

\section{Results}

\section{Ambient air pollution}

The yearly means of $\mathrm{PM}_{10}$ show that the children born and living in the region $\mathrm{O}$. west were exposed to the lowest immissions of $\mathrm{PM}_{10}$ (Table 2) as only in $2003 \mathrm{did}$ the yearly mean exceed $40.1 \mu \mathrm{g} / \mathrm{m}^{3}$. In 2001-2003 there was practically no difference between the rather steep increases in the yearly means of $\mathrm{PM}_{10}$ in the other three regions of Ostrava. After a decrease in 2004 the $\mathrm{PM}_{10}$ levels started to increase again and peaked in 2006 and 2007. In this period the levels of $\mathrm{PM}_{10}$ in the four Ostrava regions noticeably differed, and the levels of $\mathrm{PM}_{10}$ increased in the order $\mathrm{O}$. west, south, center and east. In the latter region the mean concentration of

Table 2 Weighted yearly means of $\mathrm{PM}_{10}$ and the yearly means of benzo[a]pyrene

\begin{tabular}{|c|c|c|c|c|c|c|c|c|c|}
\hline & 2001 & 2002 & 2003 & 2004 & 2005 & 2006 & 2007 & 2008 & 2009 \\
\hline PM10 & $\mu \mathrm{g} / \mathrm{m} 3$ & $\mu \mathrm{g} / \mathrm{m} 3$ & $\mu \mathrm{g} / \mathrm{m} 3$ & $\mu \mathrm{g} / \mathrm{m} 3$ & $\mu \mathrm{g} / \mathrm{m} 3$ & $\mu g / m 3$ & $\mu \mathrm{g} / \mathrm{m} 3$ & $\mu g / m 3$ & $\mu \mathrm{g} / \mathrm{m} 3$ \\
\hline Ostrava south & 47.3 & 44.9 & 50.8 & 43.7 & 48.6 & 43.9 & 37.6 & 37.0 & 39.9 \\
\hline Ostrava east & 46.6 & 50.8 & 53.3 & 40.3 & 53.4 & 60.9 & 59.8 & 47.8 & 47.0 \\
\hline Ostrava center & 44.2 & 49.8 & 54.7 & 43.3 & 50.7 & 50.4 & 44.1 & 43.2 & 42.6 \\
\hline Ostrava west & 33.9 & 40.1 & 45.8 & 27.7 & 31.8 & 40.1 & 24.2 & 26.2 & 28.7 \\
\hline $\mathrm{B}[\mathrm{a}] \mathrm{P}$ & $\mathrm{ng} / \mathrm{m} 3$ & $\mathrm{ng} / \mathrm{m} 3$ & $\mathrm{ng} / \mathrm{m} 3$ & $\mathrm{ng} / \mathrm{m} 3$ & $\mathrm{ng} / \mathrm{m} 3$ & $\mathrm{ng} / \mathrm{m} 3$ & $\mathrm{ng} / \mathrm{m} 3$ & $\mathrm{ng} / \mathrm{m} 3$ & $\mathrm{ng} / \mathrm{m} 3$ \\
\hline Ostrava east & - & - & 7.9 & 10.0 & 10.3 & 11.7 & 8.9 & 9.3 & 9.2 \\
\hline Ostrava center PZ & - & - & 7.8 & 6.5 & 9.2 & 6.8 & 6.4 & 5.1 & 5.5 \\
\hline Ostrava center MH & - & - & 7.2 & 4.3 & 4.5 & 4.9 & 4.1 & 3.9 & 4.8 \\
\hline Ostrava west & - & - & - & 2.1 & 3.2 & 3.7 & 2.2 & 3.5 & 3.3 \\
\hline
\end{tabular}

$\mathrm{B}[\mathrm{a}] \mathrm{P}$ was monitored at 4 stations: $\mathrm{O}$. center $\mathrm{PZ}=$ Privoz, $\mathrm{O}$. center $\mathrm{MH}=$ Marianske Hory (see Figure 1). 
Table 3 Numbers of children included in the present analysis stratified according to their residence and age

\begin{tabular}{lccccc}
\hline & 1st year & 2nd year & 3rd year & 4th year & 5th year \\
\hline Ostrava south & 708 & 698 & 687 & 682 & 677 \\
Ostrava east & 183 & 176 & 174 & 172 & 170 \\
Ostrava center & 348 & 326 & 315 & 298 & 289 \\
Ostrava west & 296 & 288 & 280 & 272 & 268 \\
Total & 1535 & 1488 & 1456 & 1424 & 1404 \\
\hline
\end{tabular}

$\mathrm{PM}_{10}$ in 2006 reached $61 \mu \mathrm{g} / \mathrm{m}^{3}$. The yearly means of benzo[a]pyrene are available for the period from 2003 to 2011. The lowest yearly means in the range 2.1 to $3.7 \mathrm{ng} /$ $\mathrm{m}^{3}$ of $\mathrm{B}[\mathrm{a}] \mathrm{P}$ were observed in $\mathrm{O}$. west. The highest levels in the range 7.9 to $11.7 \mathrm{ng} / \mathrm{m}^{3}$ of $\mathrm{B}[\mathrm{a}] \mathrm{P}$ were recorded by the monitoring station in $\mathrm{R} \& \mathrm{~B}$ in the region O. east. From 2003 to 2006 the yearly means of B[a]P in O. east increased by $48 \%$. The 6 months means of the winter and autumn months ranged from 12.2 to $18.7 \mathrm{ng} / \mathrm{m}^{3}$ in O. east (data not shown). B[a]P was not monitored in $\mathrm{O}$. south.

\section{Age- and region-specific morbidity of children}

Acute URI represented $47.4 \%$ of the total number of 27,368 diagnoses of acute illnesses evaluated in our study (Table 1). Their age-specific incidence rates/100 children/ year in the four Ostrava regions are shown in Figure 2. The highest incidence - 372 episodes per 100 children in the first year of life - was found in the children from the region $\mathrm{O}$. east. In the second year of life the incidence rate of URI in O. east decreased by about $50 \%$ to the level of the incidence of URI in O. south, and this similarity persisted to the 5 th year of life. The incidence rates of URI in children living in $\mathrm{O}$. center and $\mathrm{O}$. west were remarkably lower. The incidence rate of tonsillitis in the 1st year of life of children born and living in O. east (86/100 children/year) was approximately 8 times higher than in the other regions of Ostrava. It remained at the same level till the 5th year of life (Figure 3). The incidence rate of tonsillitis in the other regions of Ostrava increased with age to a maximum of $37 / 100$ children in the 5th year of life in $\mathrm{O}$. south. The incidence rate of intestinal infectious diseases was highest in the O. east children with a rate of $81 / 100$ children/year in the 1st year, decreasing to 27/100 children/year in the 3rd year (Figure 4). The incidence rates in the other 3 regions remained in the range from 6 to 35/ 100 children/year; the incidence plots for O. center and O. west were almost identical.

The children in $\mathrm{O}$. east also had the highest incidence rate of viral illnesses, namely of unspecified viral infections (ICD code B34). The rate of $86 / 100$ children/year in the 1st year decreased rather slowly to $63 / 100$ children in the 4th year (Figure 5). The incidence rates in children in the other three regions were similar, ranging from 12 to 24/ 100 children/year.

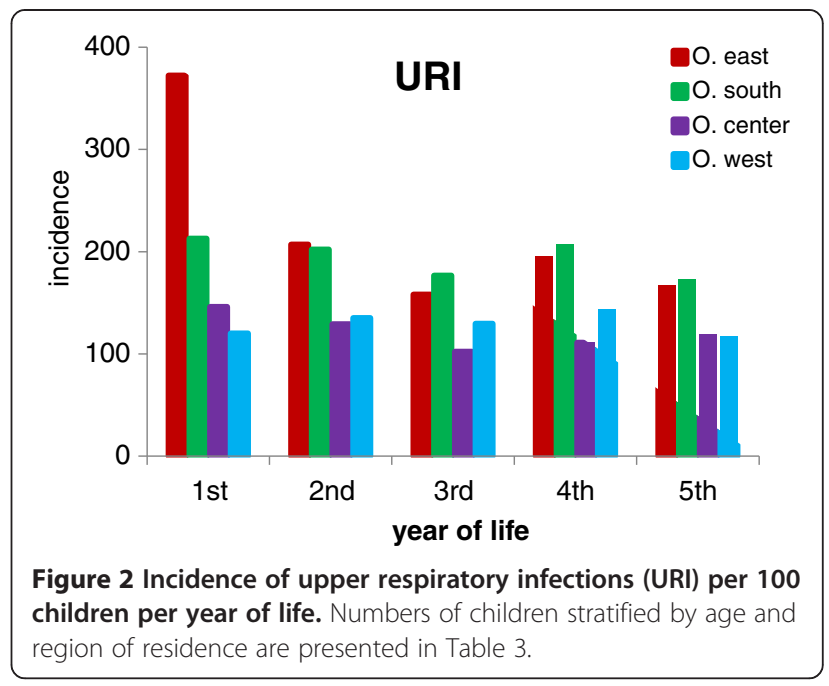

Finally, the incidence rate of pneumonia was higher in children born and living in $\mathrm{O}$. east than in the other regions. It decreased from $17 / 100$ in the 1 st year to $8 / 100$ in the 3rd year and remained approximately at this level in the 4th and 5th year (Figure 6). In O. west there was only 1 case of pneumonia in the 1st and another one in the 5th year.

The incidence of otitis media was quite low in the first three years, then peaked in the 4th year of life in O. south at 24/100 children/year. The peak incidence was also reached in the 4th year in $\mathrm{O}$. west and east and in the 5th year in O. center. The plots of the age incidence of laryngitis and tracheitis show two distinctly different pairings. Children in $\mathrm{O}$. west and $\mathrm{O}$. east had a lower incidence with a plateau from the 3rd to the 5th year of age (about 15 diagnoses/100 children/year). The other two plots (O. south and $\mathrm{O}$. center) had their highest values at about 35 diagnoses/100 children/year in the 4th and 5th year of age.

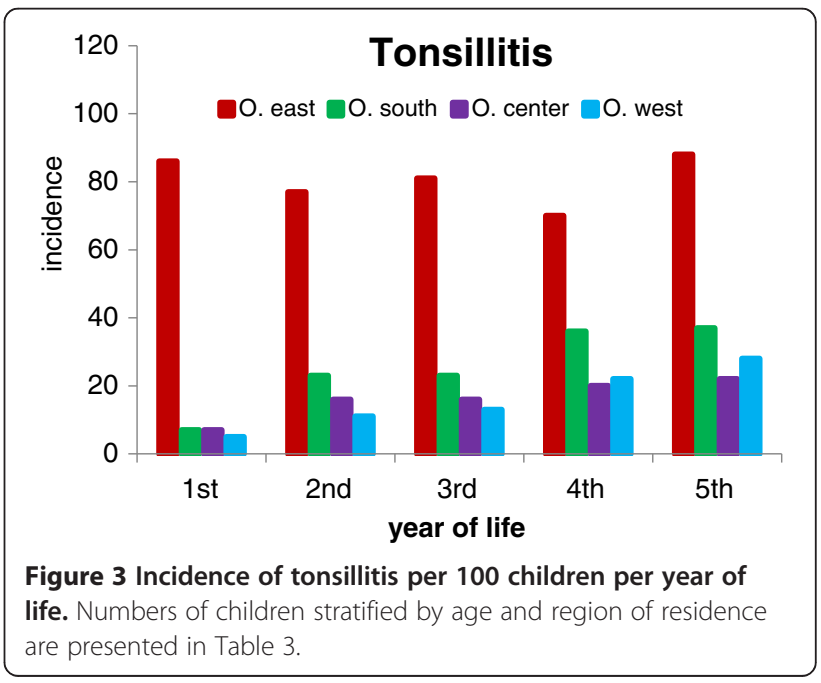




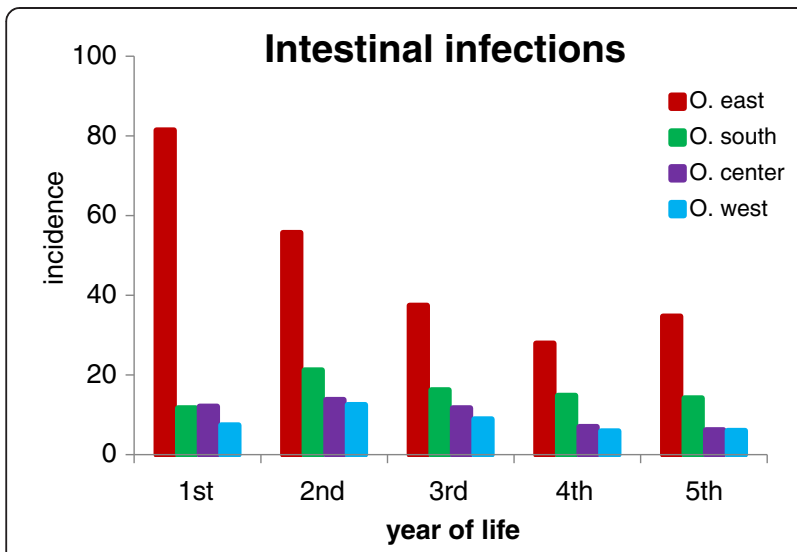

Figure 4 Incidence of intestinal infectious diseases per 100 children per year of life. Numbers of children stratified by age and region of residence are presented in Table 3 .

The incidence plots of bronchitis peak in the 4th or the 5 th year of age. The highest yearly incidence from the 2nd to the 4th year was found in children living in O. center.

\section{Covariates}

Sociodemographics, the indoor environment and other characteristics stratified by region of residence are presented in Table 4. There were several differences between families living in $\mathrm{O}$. east and in the other three regions. More mothers in $\mathrm{O}$. east attained the lowest level of education and fewer mothers attained the highest levels. More mothers smoked during pregnancy and fewer children were breastfed and attended day care. The biggest differences were in the type of housing, since in $R \& B$ (where most children in our sample from O. east lived) family houses prevail over apartment block flats and, consequently, space heating (gas, coal/

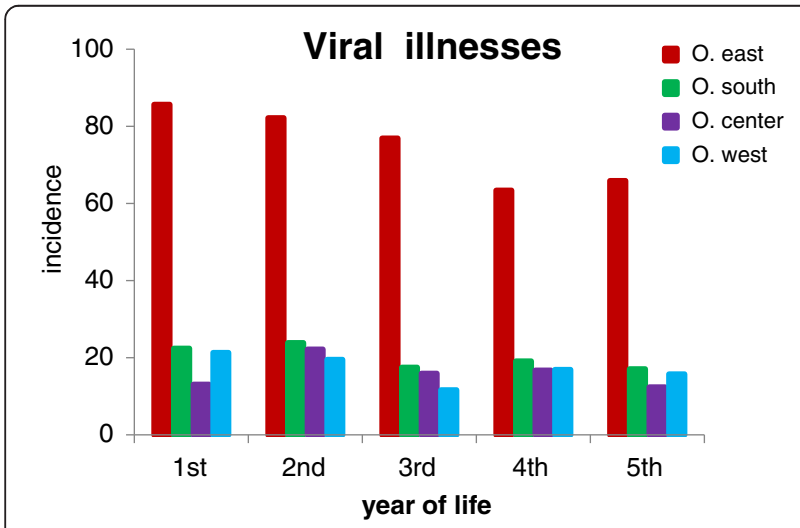

Figure $\mathbf{5}$ Incidence of viral illnesses per 100 children per year of life. The vast majority of diagnoses in $\mathrm{O}$. east were infections of unspecified site (ICD code B34). Numbers of children stratified by age and region of residence are presented in Table 3.

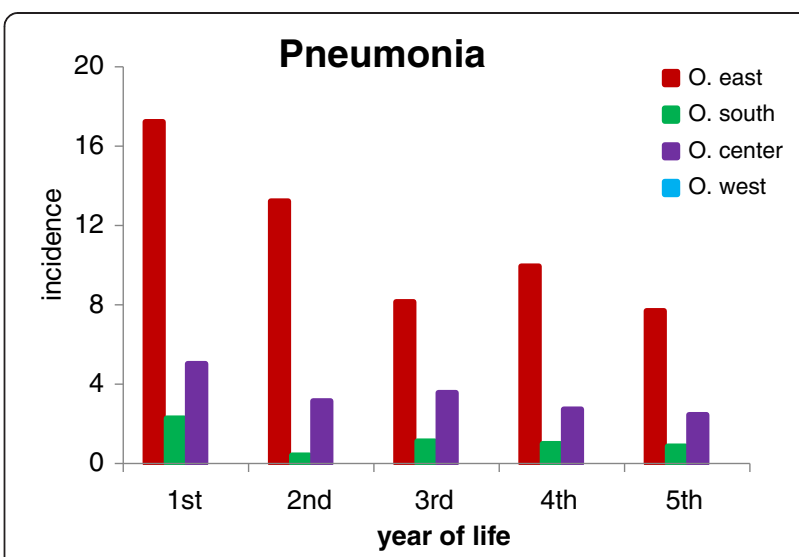

Figure 6 Incidence of pneumonia per 100 children per year of life. Numbers of children stratified by age and region of residence are presented in Table 3. In O. west there was only 1 case of pneumonia in the 1st and another one in the 5th year.

wood) and mold in flats were more frequent and gas appliances in flats were less frequent. Also, more children had siblings under 14 with allergies. However, none of these covariates confounded associations of the increased incidence of acute infections in children born and living in the $\mathrm{O}$. east region.

\section{Incidence rate ratios}

Differences between the incidence rates of illnesses in children living in the four regions of Ostrava were evaluated in two age categories: from birth to the age of 2 years and from the age of 2 to 5 years (Table 5). Associations of the incidence rates of illnesses with four level region variables were tested using negative binomial regression. As the basic level we chose residence in $\mathrm{O}$. east (Table 6). In both age categories the incidence rates of bronchitis and otitis media did not differ, while the rates of tonsillitis, viral illnesses, and intestinal infections in the regions $\mathrm{O}$. south, west and center were significantly lower than in $\mathrm{O}$. east. The rate ratios ranged from 0.51 to 0.11 . The incidence rates of URI were significantly higher than in the remaining regions in the age category of $0-2$ years, whereas in the category $2-5$ years there was no difference between the O. east and O. south. The incidence of pneumonia was significantly higher in the age category $0-2$ years and too low to be tested in the older group. The incidence of laryngitis and tracheitis in O. east varied with age; in the older category it was lower in $\mathrm{O}$. east than in $\mathrm{O}$. south and $\mathrm{O}$. center. The RRs were adjusted for gender, type of delivery, neonatal icterus treated with phototherapy, year of birth, breastfeeding, maternal age and education, atopic dermatitis, smoking of the mother, exposure to environmental tobacco smoke, having an older sibling, allergy of an older sibling, type of flat (1st year), households with a gas appliance and mold 
Table 4 Data from the maternal questionnaires

\begin{tabular}{|c|c|c|c|c|c|c|}
\hline \multicolumn{2}{|c|}{ Variables } & $\begin{array}{c}\text { O. south } \\
\%\end{array}$ & $\begin{array}{c}\text { O. east } \\
\%\end{array}$ & $\begin{array}{c}\text { O. center } \\
\%\end{array}$ & $\begin{array}{c}\text { O. west } \\
\%\end{array}$ & P. (KW) \\
\hline \multirow[t]{2}{*}{ Gender } & Boys & 49.7 & 49.2 & 55.2 & 48.3 & \\
\hline & Girls & 50.3 & 50.8 & 44.8 & 51.7 & \\
\hline \multirow[t]{2}{*}{ Delivery } & Sectio Caesarea & 17.4 & 16.4 & 19.4 & 18.7 & \\
\hline & Phototherapy* & 5.5 & 1.6 & 7.2 & 4.4 & $=0.028$ \\
\hline \multirow[t]{2}{*}{ Birth weight } & Mean (grams) & 3380 & 3380 & 3380 & 3399 & \\
\hline & SD (grams) & 478 & 492 & 481 & 455 & \\
\hline \multirow[t]{3}{*}{ Age of mothers at delivery } & $<20$ years & 4.2 & 5.5 & 6.0 & 3.4 & \\
\hline & 20 to 30 years & 64.7 & 68.9 & 67.0 & 67.8 & \\
\hline & $>30$ years & 31.0 & 25.7 & 27.0 & 28.8 & \\
\hline \multirow[t]{3}{*}{ Mother's education } & Low & 9.1 & 16.4 & 10.1 & 5.1 & \\
\hline & Middle & 40.2 & 38.3 & 35.1 & 29.7 & \\
\hline & High & 50.7 & 45.4 & 54.9 & 65.2 & \\
\hline \multirow[t]{3}{*}{ Breastfeeding } & Breast fed & 92.8 & 86.3 & 93.7 & 92.9 & $=0.009$ \\
\hline & Months - mean & 8.7 & 7.6 & 8.8 & 11.0 & \\
\hline & Months - SD & 9.1 & 8.1 & 9.1 & 20.9 & \\
\hline \multirow[t]{2}{*}{ Smoking of mothers } & During pregnancy & 12.0 & 17.5 & 18.1 & 9.1 & \\
\hline & During the study & 31.5 & 32.2 & 35.6 & 23.6 & $=0.019$ \\
\hline Exposure to ETS* & Any adult & 48.6 & 54.6 & 49.9 & 42.7 & \\
\hline Type of flat & Family house & 11.0 & 55.0 & 3.0 & 15.5 & $<0.001$ \\
\hline \multirow[t]{2}{*}{ (in the 1st year) } & Brick block flats & 23.6 & 36.8 & 36.0 & 36.1 & \\
\hline & Concrete block flats & 65.5 & 8.2 & 61.0 & 48.5 & \\
\hline \multirow[t]{3}{*}{ Type of heating } & Distant & 65.5 & 8.2 & 61.0 & 48.5 & $<0.001$ \\
\hline & Gas & 16.0 & 48.3 & 15.4 & 13.1 & \\
\hline & Coal/wood & 2.8 & 30.2 & 2.1 & 2.8 & \\
\hline Mold in flat & Yes & 24.2 & 36.8 & 12.9 & 18.9 & $<0.001$ \\
\hline Gas appliances in flat & Yes & 86.6 & 66.3 & 90.8 & 89.8 & $<0.001$ \\
\hline Other children under 14 & Yes & 51.5 & 55.7 & 48.9 & 41.2 & \\
\hline \multirow[t]{3}{*}{ Family history of allergies } & Mother & 37.2 & 44.8 & 34.2 & 33.1 & \\
\hline & Father & 21.1 & 23.0 & 25.0 & 28.7 & \\
\hline & Siblings & 20.9 & 31.1 & 26.1 & 26.4 & $=0.016$ \\
\hline \multirow[t]{4}{*}{ Pets } & Cat & 6.4 & 9.8 & 5.2 & 4.7 & \\
\hline & Dog & 20.9 & 19.1 & 17.5 & 20.9 & \\
\hline & Birds & 7.2 & 8.2 & 6.0 & 7.8 & \\
\hline & Other* & 23.6 & 20.8 & 21.8 & 22.0 & \\
\hline \multirow[t]{2}{*}{ Day care } & $3 r d$ and 4th year & 56.8 & 40.4 & 52.7 & 63.5 & $<0.001$ \\
\hline & 4th and 5th year & 89.3 & 72.9 & 89.9 & 92.9 & $<0.001$ \\
\hline
\end{tabular}

Categorical covariates except birth weight and the length of breastfeeding. KW-Kruskal Wallis test. *Phototherapy - neonatal icterus treated with phototherapy, *ETS - environmental tobacco smoke. *Other - rabbits, guinea pigs, hamsters, degus etc.

in the flat in the 1st year of life. The multivariate regressions for the age category $2-5$ years were also adjusted for recurrent wheezing, allergic rhinitis and attending daycare in the 4th and the 5th year of life.

\section{Prevalence of allergies}

The prevalence of allergies was evaluated in 1404 children of Czech ethnicity, born and living in the city of Ostrava till the age of 5 years, as children of Roma ethnicity have 
Table 5 Cumulative incidence rates of selected illnesses per 100 children of Czech ethnicity

\begin{tabular}{|c|c|c|c|c|c|c|c|c|}
\hline \multirow[b]{2}{*}{ Ostrava } & \multicolumn{4}{|c|}{ Age $0-2$ years } & \multicolumn{4}{|c|}{ Age $2-5$ years } \\
\hline & East & South & Center & West & East & South & Center & West \\
\hline Number of children & $N=176$ & $N=698$ & $N=326$ & $N=288$ & $N=170$ & $N=677$ & $N=289$ & $N=268$ \\
\hline URI & 584.7 & 419.5 & 276.7 & 253.1 & 520.6 & 559.7 & 328.7 & 392.2 \\
\hline Bronchitis & 56.3 & 60.9 & 56.1 & 43.8 & 88.8 & 81.2 & 104.2 & 89.2 \\
\hline Tonsillitis & 162.5 & 29.5 & 23.6 & 16.3 & 239.4 & 94.1 & 59.2 & 64.6 \\
\hline Viral illnesses & 166.5 & 47.4 & 35.9 & 41.7 & 205.9 & 53.5 & 47.1 & 43.7 \\
\hline Laryngitis/tracheitis & 37.5 & 33.4 & 38.7 & 19.4 & 50.0 & 93.4 & 100.0 & 47.4 \\
\hline Intestinal infections & 139.8 & 32.5 & 25.8 & 19.8 & 101.2 & 45.3 & 23.5 & 20.5 \\
\hline Otitis media & 18.2 & 16.0 & 18.7 & 15.3 & 41.8 & 56.9 & 35.6 & 39.2 \\
\hline Pneumonia & 29.5 & 2.9 & 8.0 & 0.3 & 25.9 & 3.1 & 9.0 & 0.4 \\
\hline Total & 1194.9 & 642.1 & 483.4 & 409.7 & 1273.5 & 987.1 & 707.3 & 697.0 \\
\hline
\end{tabular}

allergies rather seldom [7]. The overall prevalence of recurrent wheezing $(\mathrm{WH})$ was $14.0 \%$, and the prevalence of allergic rhinitis (AR) and atopic eczema (AE) were $10.8 \%$ and $17.8 \%$, respectively. The allergies were diagnosed by pediatricians and confirmed by allergists. Only 7 children with reported recurrent wheezing did not see an allergist. The prevalence of all three diagnoses was the highest in children born and living in the region O. east: WH 37\%, AE 35\% and AR 24\%. Also, combinations of two or three types of allergy were most frequent in O. east: $37 \%$ of children with $\mathrm{WH}$ had also $\mathrm{AE}$, while $57 \%$ of children with WH were also diagnosed with AR. Finally, $43 \%$ of children with $\mathrm{WH}$ were diagnosed with all three allergies (Table 7). Skin tests to aeroallergens were applied to most children with a suspected allergy. The highest percentages of children in all four regions of Ostrava were sensitised to pollen and mites. The children living in $\mathrm{O}$. east were sensitised less frequently than children in the other parts of Ostrava (Table 7). However, the panels of tests applied were not necessarily identical.

Table 6 Rate ratios (RR) Ostrava east/other regions

\begin{tabular}{|c|c|c|c|c|c|c|c|c|c|}
\hline \multirow[b]{2}{*}{ Age 0 to 2 years } & \multicolumn{3}{|c|}{ O. south } & \multicolumn{3}{|c|}{ O. center } & \multicolumn{3}{|c|}{ O. west } \\
\hline & RR & $\mathbf{P}$ & $95 \% \mathrm{Cl}$ & RR & $\mathbf{P}$ & $95 \% \mathrm{Cl}$ & RR & $\mathbf{P}$ & $95 \% \mathrm{Cl}$ \\
\hline URI & 0.69 & $<0.0001$ & $0.61-0.79$ & 0.45 & $<0.0001$ & $0.39-0.52$ & 0.44 & $<0.0001$ & $0.38-0.52$ \\
\hline Bronchitis & - & NS & - & - & NS & - & - & NS & - \\
\hline Tonsillitis & 0.19 & $<0.0001$ & $0.14-0.25$ & 0.16 & $<0.0001$ & $0.11-0.22$ & 0.11 & $<0.0001$ & $0.08-0.16$ \\
\hline Viral illnesses & 0.30 & $<0.0001$ & $0.28-0.38$ & 0.23 & $<0.0001$ & $0.17-0.30$ & 0.27 & $<0.0001$ & $0.21-0.35$ \\
\hline Laryngitis/tracheitis & - & NS & - & - & NS & - & 0.53 & 0.005 & $0.34-0.83$ \\
\hline Intestinal infections & 0.33 & $<0.0001$ & $0.25-0.43$ & 0.25 & $<0.0001$ & $0.18-0.35$ & 0.18 & $<0.0001$ & $0.14-0.28$ \\
\hline Otitis media & - & NS & - & - & NS & - & - & NS & - \\
\hline Pneumonia & 0.1 & 0.001 & $0.05-0.22$ & 0.31 & 0.001 & $0.15-0.64$ & - & NT & - \\
\hline Age $2-5$ years & RR & $\mathbf{P}$ & $95 \% \mathrm{Cl}$ & RR & $\mathbf{P}$ & $95 \% \mathrm{Cl}$ & RR & $\mathbf{P}$ & $95 \% \mathrm{Cl}$ \\
\hline URI & - & NS & - & 0.62 & $<0.0001$ & $0.53-0.73$ & 0.76 & $<0.0001$ & $0.65-0.88$ \\
\hline Bronchitis & - & NS & - & - & NS & - & - & NS & - \\
\hline Tonsillitis & 0.40 & $<0.0001$ & $0.32-0.50$ & 0.24 & $<0.0001$ & $0.18-0.32$ & 0.27 & $<0.0001$ & $0.20-0.35$ \\
\hline Viral illnesses & 0.28 & $<0.0001$ & $0.22-0.35$ & 0.24 & $<0.0001$ & $0.18-0.31$ & 0.22 & $<0.0001$ & $0.17-0.29$ \\
\hline Laryngitis/tracheitis & 1.88 & $<0.0001$ & $1.33-2.65$ & 1.98 & $<0.0001$ & $1.36-2.89$ & - & NS & - \\
\hline Intestinal infections & 0.51 & $<0.0001$ & $0.38-0.69$ & 0.24 & $<0.0001$ & $0.16-0.35$ & 0.22 & $<0.0001$ & $0.15-0.33$ \\
\hline Otitis media & - & NS & - & - & NS & - & - & NS & - \\
\hline Pneumonia & - & NS & - & - & NS & - & - & NS & - \\
\hline
\end{tabular}

$\mathrm{Cl}$, Confidence interval; NS, $\mathrm{P}>0.05, N T$, Not tested. Negative binomial regression, 1444 children living in the region where they were born up to the age of 2 or 5 years.

The RRs were adjusted for gender, type of delivery, neonatal icterus treated with phototherapy, year of birth, breastfeeding, maternal age and education, atopic dermatitis, smoking of the mother, exposure to environmental tobacco smoke, having an older sibling, allergy of an older sibling, type of flat (1st year),

households with a gas appliance and mold in the flat in the 1st year of life, and in the older age also for wheezing and allergic rhinitis. 
Table 7 Prevalence of wheezing and allergies among children of Czech ethnicity stratified by region of residence

\begin{tabular}{|c|c|c|c|c|c|c|c|c|c|c|c|c|c|c|}
\hline \multirow[t]{2}{*}{ Region } & \multicolumn{4}{|c|}{$\begin{array}{l}\text { Number and } \% \text { of children } \\
\quad \% \text { of children }\end{array}$} & \multicolumn{4}{|c|}{$\%$ of children with wheezing } & \multicolumn{6}{|c|}{ Skin tests, number of tested, $\%$ positive } \\
\hline & $\mathbf{N}$ & WH\% & $\mathrm{AE} \%$ & AR\% & only WH & $W H+A R+A E$ & $\mathrm{WH}+\mathrm{AE}$ & $W H+A R^{1}$ & $\mathbf{N}$ & Molds & Dog & Cat & Mites & Pollen $^{2}$ \\
\hline O. south & 677 & 10.0 & 15.2 & 9.0 & 29.4 & 23.5 & 29.4 & 41.2 & 104 & 5.8 & 14.4 & 14.4 & 25.0 & 45.2 \\
\hline O. east & 170 & 37.1 & 35.3 & 24.1 & 6.3 & 42.9 & 36.5 & 57.1 & 67 & 7.7 & 1.0 & 1.0 & 9.6 & 29.8 \\
\hline O. center & 289 & 10.7 & 13.8 & 9.3 & 46.4 & 3.0 & 19.4 & 32.3 & 76 & 17.3 & 4.8 & 5.8 & 27.9 & 35.9 \\
\hline O. west & 268 & 13.1 & 17.5 & 8.2 & 42.9 & 17.1 & 28.6 & 32.6 & 47 & 7.7 & 4.8 & 3.8 & 11.5 & 21.2 \\
\hline
\end{tabular}

Only children living in the four regions of Ostrava from birth to the age of 5 years are included. WH - wheezing, AE - atopic eczema, AR - allergic rhinitis (without differentiating between hay fever and year-round rhinitis). The prevalence of wheezing and allergies is significantly higher in Ostrava east (Kruskal Wallis test, $\mathrm{P}=$ 0.0001). Skin tests in children of Czech ethnicity - the percentages of positive tests in the children tested.

${ }^{1}$ without regards to $A E,{ }^{2}$ child positive to any species.

\section{Discussion}

The primary aim of the study was to prove or refute the hypothesis that infants, toddlers and preschool children living in the Ostrava district R\&B had higher morbidity rates than children living in other parts of Ostrava. In the Czech Republic, each child has to be registered with a pediatrician. Due to the high percentage of participating children registered with 10 pediatricians, our cohort can be considered a representative sample. We have compared the morbidity of the children by quantifying the incidence rates of acute illnesses in the first five years of life. Our results unequivocally prove the high morbidity of children born and living in the region $\mathrm{O}$. east, most of them in the district R\&B. These children had a significantly higher incidence of URI than children in O. center and O. west (in all years) and in O. south in the 1st year. Moreover, in all 5 years they had the highest incidence rates of pneumonia, tonsillitis, intestinal infectious diseases and unspecified viral illnesses. They also had the highest prevalence of recurrent wheezing, atopic dermatitis and allergic rhinitis at the age of 5 years. The lowest incidence of most illnesses was seen in children living in $\mathrm{O}$. west. The children in $\mathrm{O}$. east suffered less frequently from laryngitis and tracheitis and bronchitis than children in the other regions of Ostrava. The low incidence of tracheitis and laryngitis in $\mathrm{O}$. east may be explained by the fact that the environment in $\mathrm{O}$. east is much less urban than in O. south and center. An apparent reason for the low incidence of acute bronchitis is the high prevalence of recurrent wheezing (i.e., obstructive bronchitis) and its treatment.

Our previous study on the health of children (birth to age 10) living in the industrial district of Teplice, Czech Republic [8,9], showed that the incidences of all respiratory illnesses were at the levels seen in O. west, center or south. The only exception was the high incidence of laryngitis and tracheitis in children living in the town of Teplice. This is apparently associated with the urban environment, since the incidence of laryngitis and tracheitis in children living in the other parts of the district of Teplice was lower. The early onset of otitis media is considered as typical in many published reports [10,11]. We saw the peak incidence in the 1st and the 2nd year in children living in the district of Teplice. The highest incidence of $\mathrm{OM}$ in Ostrava children occurred in the 4th (O. south, east and west) or the 5 th year of life (O. center) [12].

In contrast to the Teplice study, the children in Ostrava were seldom diagnosed with influenza.

The four regions of Ostrava differ in the levels of pollution by PAHs and $\mathrm{PM}_{10}$. The WHO scientific review [13] stated that in addition to the carcinogenic effects of PAHs (c-PAHs, carcinogenic polycyclic aromatic hydrocarbons), there is new evidence for early biological effects of PAHs exposure in both children and adults, and that there are no reasons for changing the limit value of $B[a] P$ at $1 \mathrm{ng} / \mathrm{m}^{3}$. Miller et al. [14] used personal air monitors for $48 \mathrm{~h}$ to determine c-PAHs exposure levels (the sum of eight PAHs including $\mathrm{B}[\mathrm{a}] \mathrm{P})$ of women in the 3rd trimester of pregnancy. Their children at the age 12 months exhibited more frequent coughing and wheezing when their mothers were exposed to c-PAHs during pregnancy and the children were exposed in the postnatal period to environmental tobacco smoke. An association of acute respiratory infections, sore throat and ear infections in the first year of life of children of mothers exposed to c-PAHs in the second trimester was also suggested by the results of a study performed in Krakow, Poland, which is a region bordering MSR and similar in its industrial status and ambient air pollution [15]. The authors explained this observation by the immunotoxic activity of c-PAHs, which impairs fetal development of the immune system and is responsible for the increased susceptibility of newborns and preschool children to respiratory infections. Children living in the region $\mathrm{O}$. south had the second highest incidence rate of URI in the first year and a slightly higher incidence of URI than the children in O. east in the age 2-5. PAHs are not monitored in O. south.

Dejmek et al. [16] observed the effect of increasing concentrations of c-PAHs in polluted air on intrauterine growth retardation and low birth weight. Choi et al. [17] published the results of another study from Krakow. 
Personal exposure of mothers to $\mathrm{B}[\mathrm{a}] \mathrm{P}$ in the first trimester was $2.11 \mathrm{ng} / \mathrm{m}^{3}$ during March-May and $7.21 \mathrm{ng} / \mathrm{m}^{3}$ during December-February. This study showed a significant negative impact of c-PAHs on the growth of the fetus during the first trimester. In our study, there were significantly more newborns with a birth weight under 2,500 grams in O. south than in the other regions of Ostrava [18]. PAH-DNA adducts have been detected in cord and maternal blood [19] and placentas [20]. Prenatal exposure to c-PAHs may be associated with altered lymphocyte immunophenotypic distribution in cord blood [21] and changes in cord serum immunoglobulin E levels [22]. When exposed children were followed until school age, it was observed that prenatal exposure to c-PAHs induced behavioral deficits and neuromotoric disturbances [23-26] and increased the prevalence of asthma bronchiale [27].

Biomarkers of genotoxicity in newborns were compared in a cohort of newborns in Prague and the town of Ceske Budejovice in the southern part of the Czech Republic. B[a] $\mathrm{P}$ concentrations and DNA adducts and micronuclei in the leucocytes of cord blood were higher in Ceske Budejovice than in Prague. Moreover, logistic regression suggested a possible association of $\mathrm{B}[\mathrm{a}] \mathrm{P}$ exposure in the third trimester with the percentages of micronuclei in cord blood [28]. These results support the view that prenatal exposure to PAHs can induce a developmental dysbalance of the immune system. However, in our study we have no data on personal exposures, and the data from the monitoring station in R\&B are available only since 2003 and for O. south they are completely missing.

We have confirmed the highest prevalence of wheezing during the first 5 years of life in children born and living in the district R\&B. These children also had the highest prevalence of allergic rhinitis and of atopic eczema, which may indicate a higher probability of developing permanent asthma bronchiale [29]. The two-stage hypothesis of Gern [30] says that environmental exposures interact with genetic factors during the prenatal and postnatal periods to adversely influence the development of innate and adaptive immunity, which in turn increases the risk for allergic sensitization and atopic diseases. In the second stage, immune dysregulation in infancy increases the risk of developing lower respiratory infections that cause airway inflammation and structural changes during a particularly vulnerable period of lung development, leading to an increased risk of asthma by age 7 years. This hypothesis is applicable to the effects of c-PAHs. As far as the mechanisms of the prenatal effects of c-PAHs are concerned, it has been found that during the fetal phases of development, c-PAHs can change the methylation pattern of $\mathrm{CpG}$ cytosine in fetal DNA. Methylation of the promotor parts of genes silence their expression. Several studies reported an association of this type of prenatal effect of c-PAHs with the presence of wheezing in children at the age of 5 years.
The presently available data on environmental epigenetics of asthma bronchiale in children have been reviewed $[31,32]$. Maternal exposure to c-PAHs during pregnancy was also associated with the methylation of the promotor of the IFNY gene, which may be associated with the differentiation of naive $\mathrm{CD} 4+\mathrm{T}$ lymphocytes into proallergic TH2 helper lymphocytes [33]. The results of studies on the genotoxicity of c-PAHs performed in the Ostrava region in adults and in vitro were reviewed by Sram et al. [1].

In the WHO review [13] it is stated that there is increasing evidence for the effects of coarse particles $\left(\mathrm{PM}_{10-2.5}\right)$ on human health, independently of the effects of $\mathrm{PM}_{2.5}$. When we stratified the morbidity of $\mathrm{O}$. east children in the 1st year of life according to the year of birth, the highest incidences of URI, intestinal infectious diseases and viral illnesses were found in children born in 2003. On the other hand, the children born in 2004 had the lowest incidences of all illnesses except URI. The incidence rate of URI in the first and second year of life of children born in 2003 and 2004 was significantly higher than in children born in 2001 and 2002, and it was not associated with the season of birth. The incidence plots of URI, viral illnesses and intestinal infectious diseases (Figure 7) resemble the 2001-2004 plots of the yearly means of $\mathrm{PM}_{10}$ in Ostrava (see the data in Table 2). From the Czech Hydrometeorological Institute data [34] it follows that this oscillation in the yearly means of $\mathrm{PM}_{10}$ was common throughout the Czech Republic and was therefore due to meteorological factors. The time differences in morbidity were limited to children living in $\mathrm{O}$. east and support the view that ambient air pollution affects morbidity in infants.

Our study is a retrospective study. The data were extracted from pediatric documentation. The advantage of this approach is that the records were made at the time of illness and therefore are not memory biased. The disadvantage is, on the other hand, that the effects on morbidity of additional factors, such as children's

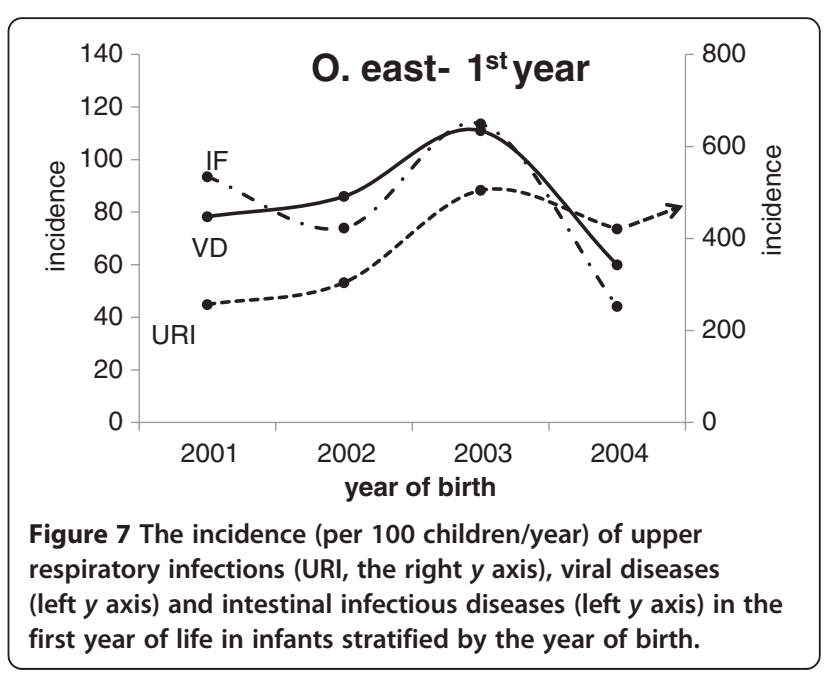


way of life (their physical activity, nutrition, etc.) cannot be followed. From the published studies (most of them concerned with schoolers) it follows that there is a connection between life style of children and their parents, the latter of which is dependent on their socioeconomic status e.g., [35], the proxy being mothers' education. In a systematic review of the studies on unfavorable health outcome related to sedentary behavior of children aged 0-4 years, only low to moderate evidence was reported for the adiposity, psychosocial health and cognitive development [36]. In our study, a high incidence of acute respiratory infections in $\mathrm{O}$. east children was already present in the 1st year of life when the vast majority of children were breastfed. Later on (in the 3rd, the 4th and the 5th year) from 40 to $90 \%$ children visited day care, which increased their risk of their being infected (Table 4).

\section{Conclusions}

In comparison with children living in the other regions of Ostrava, the children born and living for 5 years in the region Ostrava east (most of them in the highly polluted district $R \& B$ ) had: a higher incidence of upper respiratory infections, pneumonia, tonsillitis, intestinal infectious diseases and unspecified viral infections (ICD10 code B34). They also had the highest prevalence of wheezing (37\%), atopic dermatitis (35\%), allergic rhinitis (24\%) and their combinations. Among the four regions of Ostrava, the highest yearly means of $\mathrm{PM}_{10}$ and benzo[a]pyrene (in 2006) were recorded at the monitoring station in $R \& B$, whereas the lowest yearly concentrations of both $\mathrm{PM}_{10}$ and benzo[a]pyrene occurred in the region Ostrava west with a low morbidity in children. In multivariate models the effects of the region of residence on morbidity in children were not modified by any covariate. Our data are in agreement with the literature data which show that prenatal exposure to benzo[a]pyrene presents a considerable risk to multiple organ systems with negative consequences for postnatal development.

\footnotetext{
Abbreviations

AE: Atopic eczema; AR: Allergic rhinitis; B[a]P: Benzo[a]pyrene; ICD-10: International classification of diseases, tenth revision; MSR: MoravianSilesian region; NE: Northeast; O.: Ostrava; PAHs: Polycyclic aromatic hydrocarbons; c-PAHs: Carcinogenic polycyclic aromatic hydrocarbons; $\mathrm{PM}_{10}$ : Particulate matter with an aerodynamic diameter $\leq 10 \mu \mathrm{m}$; $\mathrm{PM}_{2.5}$ : Particulate matter with an aerodynamic diameter $\leq 2.5 \mu \mathrm{m}$; R\&B: Radvanice and Bartovice; RR: Rate ratio; SW: Southwest; URI: Upper respiratory infections; $\mathrm{WH}$ : Wheezing.
}

\section{Competing interests}

The authors declare that they have no competing interests.

\section{Authors' contributions}

MD collected the field data, performed the statistical analysis and drafted the manuscript. AP supervised digitalization of the field data, constructed the final database and took part in performing statistical analysis. VS was responsible for data on pollution of the city of Ostrava. SR and ER calculated the yearly means of $\mathrm{PM}_{10}$ for each locality of residence using GIS and the data from surrounding monitoring stations. ES provided advice about composition of questionnaires and analysis of ICD-10 codes. Author RJS conceived the study and participated in its coordination and in drafting the manuscript. All authors have read and approved the final manuscript.

\section{Acknowledgements}

This work was supported by the Ministry of the Environment of the Czech Republic (Airgen SP/1b3/8/08)and the Grant Agency of the Czech Republic (P $301-13458$ S). The study would not have been possible without the close cooperation of pediatricians and pediatric nurses in the city of Ostrava. We thank to Jim Dut for critically reading the manuscript.

\section{Author details}

${ }^{1}$ Institute of Experimental Medicine AS CR, Prague, Czech Republic. ${ }^{2}$ Czech Hydrometeorological Institute, Prague, Czech Republic. ${ }^{3}$ Public Health Institute in Usti nad Labem, Usti nad Labem, Czech Republic.

${ }^{4}$ Hviezdoslavova 18, Ostrava, Czech Republic.

Received: 17 June 2013 Accepted: 24 August 2013

Published: 3 September 2013

\section{References}

1. Sram RJ, Dostal M, Libalova H, Rossner PJ, Rossnerova A, Svecova V, Topinka J, Bartonova A: The European Hot Spot of B[a]P and PM2.5 Exposure-The Ostrava Region, Czech Republic: Health Research Results. ISRN Public Health; 2013. doi:10.1155/2013/416701.

2. Svecova V, Topinka J, Solansky I, Rossner P Jr, Sram RJ: Personal exposure to carcinogenic polycyclic aromatic hydrocarbons in the Czech Republic. J Expo Sci Environ Epidemiol 2013, 23:350-355.

3. Cenia Czech Environmental Information Agency: State of the Environment in Different Regions of the Czech Republic in 2009. CENIA: in Czech; 2011.

4. Cernikovsky L: Air pollution by suspended particles PM10 and PM2.5 in the city of Ostrava 2006-2011(in Czech). Ochrana ovzdusi 2012, 6:13-18.

5. Keder J: Recognition of sources possibly polluting a particular locality using a backward trajectory method (in Czech). Ochrana ovzdusi 2012, 6:24-26.

6. Williams RJ, Wats RR, Hartlage TA, Phillips L, Lewtas J, Dobias L, Havrankova J, Volf J, Kellogg RB, Willis RD, Novak J: Ostrava human exposure and biomarker study. United States Environmental Protection Agency. EPA/600/ R-97/069. http://nepis.epa.gov/Exe/ZyNET.exe/30003JYQ.TXT?ZyActionD= ZyDocument\&Client=EPA\&Index=1995+Thru+1999\&File=D\%3a\%5cZYFILES\% 5cINDEX+DATA\%5c95THRU99\%5cTXT\%5c00000009\%5c30003JYQ. TXT\&User=anonymous\&Password=anonymous\&Display=hpfrw\& MaximumPages=5\&Query=fname\%3d\%2230003JYQ.TXT\%22.

7. Dostal M, Topinka J, Sram RJ: Comparison of the health of Roma and nonRoma children living in the district of Teplice. Int J Public Health 2010 55:435-441.

8. Dostal M, Prucha M, Rychlikova E, Pastorkova A, Sram RJ: Morbidity of children in the districts of Teplice and Prachatice: A longitudinal ecologic study (in Czech). Ochrana ovzdusi 2012, 5:11-19.

9. Sram RJ, Binkova B, Dostal M, Merkerova-Dostalova M, Libalova H, Milcova A, Rossner PJ, Rossnerova A, Schmuczerova J, Svecova V, Topinka J, Votavova $\mathrm{H}$ : Health impact of air pollution to children. Int J Hyg Environ Health; 2013. doi:10.1016/j.ijheh.2012.12.001.

10. Macintyre EA, Karr CJ, Koehoorn M, Demers P, Tamburic L, Lencar C, Braue M: Otitis media incidence and risk factors in a population-based birth cohort. Paediatr Child Health 2010, 15:437-42.

11. Heinrich J, Raghuyamshi VS: Air pollution and otitis media: a review of evidence from epidemiologic studies. Curr Allergy Asthma Rep 2004, 4:302-309.

12. Dostal M, Pastorkova A, Lochmanova A, Sram RJ: Incidence of otitis media in children living in heavy polluted environment (in Czech). Ochrana ovzdusi 2012, 5:20-24.

13. WHO: REVIHAAP Project, WHO Regional Office for Europe; 2013. http://www.euro who.int/en/what-we-do/health-topics/environment-and-health/air-quality/ publications/2013/review-of-evidence-on-health-aspects-of-air-pollutionrevihaapinterim-report.

14. Miller RL, Garfinkel R, Horton M, Camann D, Perera FP, Whyatt RM, Kinney PL: Polycyclic aromatic hydrocarbons, environmental tobacco smoke, and respiratory symptoms in an inner-city birth cohort. Chest 2004, 126:1071-1078. 
15. Jedrychowski W, Galas A, Pac A, Flak E, Camman D, Rauh V, Perera F: Prenatal ambient air exposure to polycyclic aromatic hydrocarbons and the occurrence of respiratory symptoms over the first year of life. Eur J Epidemiol 2005, 20:775-782.

16. Dejmek J, Selevan SG, Benes I, Solansky I, Sram RJ: Fetal growth and maternal exposure to particulate matter during pregnancy. Environ Health Perspect 1999, 107:475-480.

17. Choi $H$, Wang L, Lin $X$, Spengler JD, Perera FP: Fetal window of vulnerability to airborne polycyclic aromatic hydrocarbons on proportional intrauterine growth restriction. PLoS One 2012. doi:10.1371/ journal.pone.0035464.

18. Pastorkova A, Dostal M, Sram RJ: Project Airgen: Children's health in Ostrava - congenital malformations (in Czech). Ochrana ovzdusi 2011, 5-6:17-22.

19. Perera F, Tang D, Whyatt $R$, Lederman SA, Jedrychowski W: DNA damage from polycyclic aromatic hydrocarbons measured by benzo[a]pyreneDNA adducts in mothers and newborns from Northern Manhattan, the World Trade Center Area, Poland, and China. Cancer Epidemiol Biomarkers Prev 2005, 14:709-714.

20. Topinka J, Binkova B, Mrackova G, Stavkova Z, Peterka M, Benes I, Dejmek J Lenicek J, Pilcik T, Sram RJ: Influence of GSTM1 and NAT2 genotypes on placental DNA adducts in an environmentally exposed population. Environ Mol Mutagen 1997, 30:184-195.

21. Herr CE, Dostal M, Ghosh R, Ashwood P, Lipsett M, Pinkerton KE, Sram R, Hertz-Picciotto I: Air pollution exposure during critical time periods in gestation and alterations in cord blood lymphocyte distribution: a cohort of livebirths. Environ Health 2010. doi:10.1186/1476-069X-9-46.

22. Herr CE, Ghosh R, Dostal M, Skokanova V, Ashwood P, Lipsett M, Joad JP, Pinkerton KE, Yap PS, Frost JD, Sram R, Hertz-Picciotto I: Exposure to air pollution in critical prenatal time windows and $\lg E$ levels in newborns. Pediatr Allergy Immunol 2011, 22:75-84.

23. McCallister MM, Maguire M, Ramesh A, Aimin Q, Liu S, Khoshbouei H, Aschner M, Ebner FF, Hood DB: Prenatal exposure to benzo(a)pyrene impairs laterlife cortical neuronal function. Neurotoxicology 2008, 29:846-854.

24. Perera FP, Li Z, Whyatt R, Hoepner L, Wang S, Camann D, Rauh S: Prenatal airborne polycyclic aromatic hydrocarbon exposure and child IQ at age 5 years. Pediatrics 2009. doi:10.1542/peds.2008-3506.

25. Sheng L, Ding X, Ferguson M, McCallister M, Rhoades R, Maquire M, Ramesh A, Aschner M, Campbell D, Levitt P, Hood DB: Prenatal polycyclic aromatic hydrocarbon exposure leads to behavioral deficits and downregulation of receptor tyrosine kinase MET. Toxicol Sci 2010, 118:625-634.

26. Perera FP, Wang S, Vishnevetsky J, Zhang B, Cole KJ, Tang D, Rauh V, Phillips $\mathrm{DH}$ : Polycyclic aromatic hydrocarbons-aromatic DNA adducts in cord blood and behavior scores in New York city children. Environ Health Perspect 2011, 119:1176-1181.

27. Perera F, Tang WY, Herbstman J, Tang D, Levin L, Miller R, Ho SM: Relation of DNA methylation of $5^{\prime}-\mathrm{CpG}$ island of ACSL3 to transplacental exposure to airborne polycyclic aromatic hydrocarbons and childhood asthma. PLoS One 2009. doi:10.1371/journal.pone.0004488.

28. Rossnerova A, Spatova M, Pastorkova A, Tabashidze N, Veleminsky MJ, Balascak I, Solansky I, Sram RJ: Micronuclei levels in mothers and their newborns from regions with different types of air pollution. Mutat Res 2011, 715:72-78

29. Castro-Rodriguez JA, Holberg CJ, Wright AL, Martinez FD: A clinical index to define risk of asthma in young children with recurrent wheezing. Am J Respir Crit Care Med 2000, 162:1403-1406.

30. Gern EJ: The urban environment and childhood asthma study. J Allergy Clin Immuno 2010, 125:545-549.

31. Ho SM: Environmental epigenetics of asthma: an update. J Allergy Clin Immunol 2010, 126:453-465.

32. Kabesch M, Michel S, Tost J: Epigenetic mechanisms and the relationship to childhood asthma. Eur Respir J 2010, 36:950-961.

33. Rosa MJ, Jung KH, Perzanowski MS, Kelvin EA, Darling KW, Camann DE, Chillrud SN, Whyatt RM, Kinney PL, Perera FP, Miller RL: Prenatal exposure to polycyclic aromatic hydrocarbons, environmental tobacco smoke and asthma. Respir Med 2011, 105:869-876.

34. Czech Institute of Hydrometeorology: 09/17/2011. http://portal.chmi.cz/files/ portal/docs/uoco/isko/tab_roc/2009_enh/cze/index_cz.html.

35. Tandon PS, Zhou C, Sallis JF, Cain KL, Frank LD, Saelens BE: Home environment relationships with childrens' physical activity, sedentary time, and screen time by socioeconomic status. Int j BehavvNutr Phys Act; 2012. doi:10.1186/1479-5868-9-88

36. LeBlanc AG, Spence JC, Carson V, Connor Gorber S, Dillman C, Janssen I, Kho ME, Stearns JA, Timmons BW, Tremblay MS: Systematic review of sedentary behaviour and health indicators in the early years (aged 0-4 years). Appl Physiol Nutr Metab 2012, 37:753-72.

doi:10.1186/1476-069X-12-74

Cite this article as: Dostal et al:: Comparison of child morbidity in regions of Ostrava, Czech Republic, with different degrees of pollution: a retrospective cohort study. Environmental Health 2013 12:74.

\section{Submit your next manuscript to BioMed Central and take full advantage of:}

- Convenient online submission

- Thorough peer review

- No space constraints or color figure charges

- Immediate publication on acceptance

- Inclusion in PubMed, CAS, Scopus and Google Scholar

- Research which is freely available for redistribution 